\title{
PSORIASIS AND THE RELATIONSHIP WITH FOOD: INTEGRATIVE REVIEW
}

Psoríase e a relação com a alimentação: revisão integrativa

Psoriasis y la relación con los alimentos: revisión integradora

Thaís Verdolin Formiga ${ }^{1}$, Marynara Resendes Parreao ${ }^{1}$, Bárbara Paixão de Gois $^{2}$, Araída Dias Pereira* ${ }^{3}$

${ }^{1}$ Discente do curso de Nutrição da Universidade Federal do Tocantins (UFT), Palmas-TO, Brasil.

${ }^{2}$ Nutricionista, Mestranda no programa de Pós-Graduação em Nutrição e Saúde da Universidade Federal de Goiás (PPGNUT-UFG), Goiânia-GO, Brasil.

${ }^{3}$ Professora Doutora do curso de Nutrição da Universidade Federal do Tocantins (UFT), Palmas-TO, Brasil. Email: araida@mail.uft.edu.br

*Correspondência: Laboratório de Pesquisa Clínica, Curso de Nutrição, Universidade Federal do Tocantins., Av. NS 15, 109 Norte, Palmas, Tocantins, Brasil.CEP:77.010-090.araida@mail.uft.edu.br

Artigo recebido em 23/06/2020 aprovado em 03/-05/2021 publicado em 04/06/2021.

\begin{abstract}
Psoriasis is a chronic inflammatory disease of the skin and joints, autoimmune, and is associated with several comorbidities. The eating pattern can influence both in the prevention, treatment or its cause. This integrative review sought to understand the relation between food and psoriasis, as well as the influence and interaction of certain nutrients with it. A scientific literature survey was carried out regarding the evidence of studies on the reduction or increase in the severity of psoriasis influenced by food. It can be observed that some foods have a triggering action, such as pepper and gluten, and others collaborate for a clinical improvement, such as fish and olive oil, foods present in a Mediterranean diet. Thus, individualized nutritional care for psoriatic patients is important, so that the best nutritional management strategy can be adopted.
\end{abstract}

Keywords: Food, Diet, Nutrients, Psoriasis.

\section{RESUMO}

A psoríase é uma doença inflamatória crônica da pele e articulações, autoimune, e está associada a diversas comorbidades. $O$ padrão alimentar pode influenciar, tanto na prevenção, tratamento ou causa da doença. Esta revisão integrativa buscou conhecer a relação dos alimentos com a psoríase, bem como, a influência e interação de determinados nutrientes com a doença. Realizou-se um levantamento na literatura científica quanto a evidência de estudos sobre a redução ou aumento da gravidade da psoríase influenciada pela alimentação. Pôde-se observar que alguns alimentos têm ação desencadeadora, como a pimenta e o glúten, e outros colaboram para melhora clínica, como peixe e azeite, alimentos presentes em uma dieta mediterrânea. Dessa forma, é importante o cuidado nutricional individualizado dos pacientes psoriáticos, de modo que a melhor estratégia de manejo nutricional possa ser adotada.

Palavras-chave: Alimento, Dieta, Nutrientes, Psoríase.

\section{RESUMEN}

La psoriasis es una enfermedad inflamatoria crónica de la piel y las articulaciones, autoinmune, y se asocia con varias comorbilidades. El patrón de alimentación puede influir tanto en la prevención como en el tratamiento o la causa de la enfermedad. Esta revisión integradora buscó comprender la relación entre la alimentación y la psoriasis, así como la influencia e interacción de ciertos nutrientes con la enfermedad. Se realizó una encuesta en la literatura científica sobre la evidencia de estudios sobre la reducción o aumento de la gravedad de la psoriasis 
influenciada por los alimentos. Se observó que algunos alimentos tienen una acción desencadenante, como la pimienta y el gluten, y otros colaboran para la mejora clínica, como el pescado y el aceite de oliva, alimentos presentes en la dieta mediterránea. Por lo tanto, la atención nutricional individualizada para los pacientes psoriásicos es importante, para que se pueda adoptar la mejor estrategia de manejo nutricional.

Palabras clave: Alimentación, Dieta,Nutrientes, Psoriasis.

\section{INTRODUCTION}

Psoriasis is a skin disease described since the Christian Era and for many years it was confused with leprosy (HULSE, 1975), until the 19th century, when it was differentiated, by Robert Willian (PATALAY et al., 2008). According to the International Federation of Psoriasis Associations (IFPA) and the Brazilian Association of Psoriasis, Psoriatic Arthritis and Other Chronic Skin (Psoriasis Brazil) (2021), the disease affects approximately 125 million people worldwide.

The incidence varies among demographic regions, being lower in certain countries, such as China (DING et al., 2012), Taiwan (CHANG et al., 2009) and higher in European countries, such as the United Kingdom (GELFAND et al., 2005) and Norway (BRAATHEN et al., 1989). In addition to the USA, which $2 \%$ of the population is affected (STERN et al., 2004). According to Psoriasis Brazil, an estimated 5 million people are affected in the country. In general, there is a higher prevalence in adults compared to other age groups (KURD; GELFAND, 2009) and affects both sexes (GELFAND et al., 2004).

The term psoriasis arose from the Greek psoriasis, which means itchy rash (FOX, 1915), it is a chronic inflammatory disease of the skin and joints (BOEHNCKE; SCHON, 2015), autoimmune, mediated by the defense cells TCD4 and TCD8 lymphocytes. These markers would cause the over proliferation of proinflammatory cytokines, such as interferon- $\gamma$, interleukin 1 (IL-1), interleukin 6 (IL-6) and tumor necrosis factor alpha (TNF- $\alpha)$, causing skin lesions and consequently, the chronic inflammatory state (RENDON; SCHAKEL, 2019).

This disease is classified according to the appearance and location of its lesions, and is commonly found on the scalp, nails, sacral and palmoplantar region, however, it can be identified anywhere on the body (KIM et al., 2017), classified into psoriasis vulgaris, reverse psoriasis, guttate psoriasis, pustular psoriasis, and erythrodermic psoriasis, which can form erythematous plaques, of different sizes and shapes (RENDON; SCHAKEL, 2019).

The chronic inflammation produced in the skin may be associated with systemic changes in the body and they are susceptible to other inflammatorybased problems and other chronic diseases, for example, insulin resistance, changes in the lipid profile, obesity, cardiovascular diseases, high blood pressure, diabetes type 2 mellitus and dyslipidemia (TAKESHITA et al., 2017).

So, quality of life can be impacted, even when using medication for treatment (KORMAN et al., 2016), however studies indicate that nutritional treatment can ensure a better clinical situation according to the dietary pattern and the practice of physical activities. At the same time, these two factors can play triggering roles for the development of psoriasis. Therefore, food could influence both prevention, cause and treatment, due to the interaction of food nutrients with the disease (BARREA et al., 2016).

Since food interferes in psoriasis in different ways and there are few studies that relate these aspects, this literature review aims to understand the 
relationship of some foods with chronic inflammatory skin disease, focusing on the influence and interaction of nutrients with the disease.

\section{MATERIAL AND METHODS}

A search was carried out using the descriptors: "psoriasis and diet therapy" and "psoriasis and food". The inclusion criteria were complete articles available electronically, whose results privileged aspects related to the interaction of food and nutrients with psoriasis. Articles published since 2010 were included. The bibliographic survey was carried out on three scientific websites: Latin American Literature in Health Sciences (LILACS), PubMed and Scielo.

Data collection took place in four stages. The first one consisting of an advanced search on scientific websites, in which, a total of 848 studies were obtained: PubMed, 827; LILACS, 14; Scielo 7. In the second stage, filtering by inclusion and exclusion criteria was carried out. According to the criteria established for the selection and identification process, 449 studies were selected: 440 from PubMed, 4 from LILACS and 5 from Scielo. In the third stage, the abstracts were read, and 439 articles were excluded, as they did not address psoriasis, the effects of food or did not relate to diet therapy and food. In the fourth and last stage, the 10 selected articles were read in full.

\section{RESULTS AND DISCUSSION}

After reading the articles in full, two tables were constructed with the synthesis of the data, ordered by types of studies and divided into positive and negative factors. The results were discussed throughout the text. Chart 1 represents the overview of 8 selected publications, highlighting the objectives, methodological aspects and positive results. Table 2 represents the overview of 2 selected publications, highlighting the objectives, methodological aspects and negative results.

Chart 1- Description of the articles that had a positive impact, sorted by type of study.

\begin{tabular}{|c|c|c|c|c|c|}
\hline Title & Author/Year & $\begin{array}{l}\text { Type of study/ } \\
\text { Sample }\end{array}$ & Objectives & Results & Limitations \\
\hline $\begin{array}{l}\text { Diet and } \\
\text { physical } \\
\text { exercise in } \\
\text { psoriasis: a } \\
\text { randomized } \\
\text { controlled trial. }\end{array}$ & $\begin{array}{c}\text { Naldi et al./ } \\
2014\end{array}$ & $\begin{array}{l}\text { A randomized } \\
\text { controlled trial/ } \\
303 \text { patients }\end{array}$ & $\begin{array}{l}\text { Evaluate the } \\
\text { impact of } \\
\text { dietary } \\
\text { intervention } \\
\text { linked to } \\
\text { physical } \\
\text { exercise for } \\
\text { weight loss in } \\
\text { individuals } \\
\text { with psoriasis } \\
\text { and overweight } \\
\text { or obesity. }\end{array}$ & $\begin{array}{l}\text { It reduced the } \\
\text { severity of psoriasis } \\
\text { in patients with } \\
\text { active disease, } \\
\text { treated systemically. }\end{array}$ & $\begin{array}{l}\text { Little data } \\
\text { collection on } \\
\text { quality of life. } \\
\text { Collected data: } \\
\text { BMI, waist } \\
\text { circumference and } \\
\text { biochemical } \\
\text { parameters. }\end{array}$ \\
\hline $\begin{array}{c}\text { Energy- } \\
\text { restricted, n-3 } \\
\text { Polyunsaturated } \\
\text { Fatty Acids- } \\
\text { Rich Diet } \\
\text { Improves the } \\
\text { Clinical } \\
\text { Response to }\end{array}$ & $\begin{array}{c}\text { Guida } \text { et al./ } \\
2014\end{array}$ & $\begin{array}{l}\text { A randomized } \\
\text { controlled trial/ } \\
44 \text { patients }\end{array}$ & $\begin{array}{l}\text { Evaluate the } \\
\text { action of an } \\
\text { energy- } \\
\text { restricted diet, } \\
\text { enriched with } \\
\text { n-3 } \\
\text { polyunsaturated } \\
\text { fatty acids and }\end{array}$ & $\begin{array}{l}\text { In psoriatic obese } \\
\text { patients, an energy- } \\
\text { restricted diet } \\
\text { designed to increase } \\
\text { n-3 and reduce n-6 } \\
\text { PUFAs, improved } \\
\text { the clinical } \\
\text { outcomes of the }\end{array}$ & $\begin{array}{l}\text { There were no } \\
\text { limitations } \\
\text { reported in the } \\
\text { study. }\end{array}$ \\
\hline
\end{tabular}




\begin{tabular}{|c|c|c|c|c|c|}
\hline $\begin{array}{c}\text { Immuno- } \\
\text { Modulating } \\
\text { Drugs in Obese } \\
\text { Patients with } \\
\text { Plaque-Type } \\
\text { Psoriasis: A } \\
\text { Randomized } \\
\text { Control } \\
\text { Clinical Trial. }\end{array}$ & & & $\begin{array}{c}\text { low in n-6 } \\
\text { polyunsaturated } \\
\text { fatty acids, on } \\
\text { metabolic } \\
\text { markers and } \\
\text { clinical results } \\
\text { of obese } \\
\text { patients with } \\
\text { psoriasis. } \\
\end{array}$ & disease. & \\
\hline $\begin{array}{l}\text { A pilot study } \\
\text { assessing the } \\
\text { effect of } \\
\text { prolonged } \\
\text { administration } \\
\text { of high daily } \\
\text { doses of } \\
\text { vitamin D on } \\
\text { the clinical } \\
\text { course of } \\
\text { vitiligo and } \\
\text { psoriasis. }\end{array}$ & $\begin{array}{c}\text { Finamor et al./ } \\
2013\end{array}$ & $\begin{array}{l}\text { Pilot clinical trial/ } \\
9 \text { patients with } \\
\text { psoriasis and } 16 \\
\text { patients with } \\
\text { vitiligo }\end{array}$ & $\begin{array}{l}\text { Evaluate the } \\
\text { efficiency and } \\
\text { safety of long- } \\
\text { term treatment } \\
\text { with high doses } \\
\text { of vitamin D3 } \\
\text { in patients with } \\
\text { psoriasis and } \\
\text { vitiligo. }\end{array}$ & $\begin{array}{l}\text { The clinical } \\
\text { condition of the } 9 \\
\text { patients improved } \\
\text { during treatment. }\end{array}$ & $\begin{array}{l}\text { Small sample } \\
\text { size. }\end{array}$ \\
\hline $\begin{array}{l}\text { Nutrition and } \\
\text { psoriasis: is } \\
\text { there any } \\
\text { association } \\
\text { between the } \\
\text { severity of the } \\
\text { disease and } \\
\text { adherence to } \\
\text { the } \\
\text { Mediterranean } \\
\text { diet? }\end{array}$ & $\begin{array}{l}\text { Barrea et al.I } \\
\quad 2015 \text { a }\end{array}$ & $\begin{array}{l}\text { Cross-sectional } \\
\text { case control } \\
\text { study/ } \\
62 \text { patients }\end{array}$ & $\begin{array}{l}\text { Investigate the } \\
\text { relationship } \\
\text { between } \\
\text { adherence to } \\
\text { the } \\
\text { Mediterranean } \\
\text { diet and the } \\
\text { severity of } \\
\text { psoriasis, and } \\
\text { to evaluate } \\
\text { patients with } \\
\text { psoriasis } \\
\text { without } \\
\text { previous } \\
\text { treatment. }\end{array}$ & $\begin{array}{l}\text { The association } \\
\text { between the } \\
\text { Mediterranean diet } \\
\text { and the severity of } \\
\text { psoriasis, provides } \\
\text { possible beneficial } \\
\text { effects. }\end{array}$ & $\begin{array}{l}\text { Small sample size } \\
\text { and study design. }\end{array}$ \\
\hline $\begin{array}{c}\text { Association } \\
\text { Between } \\
\text { Mediterranean } \\
\text { Anti- } \\
\text { inflammatory } \\
\text { Dietary Profile } \\
\text { and Severity of } \\
\text { Psoriasis. }\end{array}$ & $\begin{array}{c}\text { Phan et al.I } \\
2018\end{array}$ & $\begin{array}{l}\text { Cohort study/ } \\
3557 \text { patients }\end{array}$ & $\begin{array}{l}\text { Assess the } \\
\text { association } \\
\text { between a score } \\
\text { that represents } \\
\text { adherence to } \\
\text { the } \\
\text { Mediterranean } \\
\text { diet, and the } \\
\text { onset and/or } \\
\text { severity of } \\
\text { psoriasis. }\end{array}$ & $\begin{array}{l}\text { There was an anti- } \\
\text { inflammatory } \\
\text { association between } \\
\text { a Mediterranean diet } \\
\text { and the severity of } \\
\text { psoriasis. }\end{array}$ & $\begin{array}{c}\text { Participants were } \\
\text { all volunteers, and } \\
\text { the use of a } \\
\text { psoriasis } \\
\text { questionnaire } \\
\text { derived from a } \\
\text { self-questionnaire. }\end{array}$ \\
\hline $\begin{array}{c}\text { Dietary } \\
\text { Behaviors in } \\
\text { Psoriasis: } \\
\text { Patient- } \\
\text { Reported } \\
\text { Outcomes from } \\
\text { a U.S. National } \\
\text { Survey. }\end{array}$ & $\begin{array}{c}\text { Afifi } \\
\text { et al./ } 2017\end{array}$ & $\begin{array}{l}\text { Cohort study/ } \\
1206 \text { patients }\end{array}$ & $\begin{array}{l}\text { Quantify the } \\
\text { nutrient intake } \\
\text { in psoriatic } \\
\text { patients } \\
\text { compared to } \\
\text { controls, } \\
\text { identify popular } \\
\text { dietary } \\
\text { interventions } \\
\text { and the } \\
\text { influence on } \\
\text { improvement, } \\
\text { and understand } \\
\text { patients' } \\
\text { attitudes and }\end{array}$ & $\begin{array}{l}\text { Patients reported } \\
\text { that skin } \\
\text { improvement was } \\
\text { greater after the } \\
\text { reduction of alcohol, } \\
\text { gluten, fennel and } \\
\text { after adding fish oil, } \\
\text { vegetables and } \\
\text { vitamin D to the } \\
\text { diet. }\end{array}$ & $\begin{array}{l}\text { Potential for } \\
\text { response bias, } \\
\text { predominance of } \\
\text { women, white } \\
\text { race, living in } \\
\text { urban areas and } \\
\text { time lapse } \\
\text { between patient } \\
\text { data collection } \\
\text { and control } \\
\text { collection. }\end{array}$ \\
\hline
\end{tabular}




\begin{tabular}{|c|c|c|c|c|c|}
\hline & & & $\begin{array}{c}\text { conceptions } \\
\text { about the role } \\
\text { of diet. }\end{array}$ & & \\
\hline $\begin{array}{c}\text { Coffee } \\
\text { Consumption } \\
\text { Metabolic } \\
\text { Syndrome and } \\
\text { Clinical } \\
\text { Severity of } \\
\text { Psoriasis: Good } \\
\text { or Bad Stuff? }\end{array}$ & $\begin{array}{c}\text { Barrea et al./ } \\
2018\end{array}$ & $\begin{array}{l}\text { Cross-sectional } \\
\text { case-control } \\
\text { study/ } \\
221 \text { patients }\end{array}$ & $\begin{array}{l}\text { Assess the } \\
\text { association } \\
\text { between coffee } \\
\text { consumption } \\
\text { and the clinical } \\
\text { severity of } \\
\text { psoriasis. }\end{array}$ & $\begin{array}{l}\text { Coffee intake had a } \\
\text { beneficial effect on } \\
\text { the clinical severity } \\
\text { of psoriasis. }\end{array}$ & $\begin{array}{l}\text { Psoriatic patients } \\
\text { who consumed } \\
\text { decaffeinated } \\
\text { coffee were not } \\
\text { included. }\end{array}$ \\
\hline
\end{tabular}

Chart 2 - Description of studies that presented a negative impact, sorted by type.

\begin{tabular}{|c|c|c|c|c|c|}
\hline Title & Author/Year & $\begin{array}{c}\text { Type of study/ } \\
\text { Sample }\end{array}$ & Objectives & Results & Limitations \\
\hline $\begin{array}{c}\text { Association } \\
\text { Between Coeliac } \\
\text { Disease and } \\
\text { Psoriasis: Italian } \\
\text { Primary Care } \\
\text { Multicentre } \\
\text { Study. }\end{array}$ & $\begin{array}{c}\text { Bastiani et al./ } \\
2015\end{array}$ & $\begin{array}{l}\text { Multicenter } \\
\text { clinical trial/ } \\
218 \text { patients }\end{array}$ & $\begin{array}{l}\text { Evaluate the } \\
\text { prevalence of } \\
\text { celiac disease in } \\
\text { patients with } \\
\text { psoriasis, and } \\
\text { response to a } \\
\text { gluten-free diet } \\
\text { in individuals } \\
\text { with psoriasis } \\
\text { and celiac } \\
\text { disease in } \\
\text { primary care. }\end{array}$ & $\begin{array}{l}\text { High prevalence of } \\
\text { celiac disease, so } \\
\text { gluten can act as a } \\
\text { trigger in psoriasis, } \\
\text { and improvement of } \\
\text { skin lesions in celiac } \\
\text { disease under a } \\
\text { gluten-free diet. }\end{array}$ & $\begin{array}{l}\text { Small number of } \\
\text { patients with } \\
\text { psoriasis and } \\
\text { with evidence of } \\
\text { associated celiac } \\
\text { disease. } \\
\text { It was not a } \\
\text { blind } \\
\text { assessment. }\end{array}$ \\
\hline $\begin{array}{l}\text { Pilot study on } \\
\text { foods to avoid in } \\
\text { psoriasis } \\
\text { sufferers. }\end{array}$ & $\begin{array}{l}\text { Festugato/ } \\
2011\end{array}$ & $\begin{array}{l}\text { Case control } \\
\text { study/ } \\
43 \text { patients }\end{array}$ & $\begin{array}{l}\text { Highlight some } \\
\text { foods that can } \\
\text { act as a trigger } \\
\text { and/or } \\
\text { aggravating } \\
\text { factor in } \\
\text { psoriasis and } \\
\text { enable } \\
\text { individual } \\
\text { strategies for } \\
\text { foods that } \\
\text { should be } \\
\text { introduced. }\end{array}$ & $\begin{array}{l}\text { Suspension of some } \\
\text { foods, such as } \\
\text { pepper, contributed } \\
\text { to a better treatment } \\
\text { result. }\end{array}$ & $\begin{array}{c}\text { Any type of } \\
\text { score was used. }\end{array}$ \\
\hline
\end{tabular}

Nine of the ten articles selected were from foreign journals and were available in English. Only five in Portuguese. Considering the time constraint, it was possible to verify that this theme is not recent in the literature, it has been studied since 1952. However, only in the last ten years it has been more discussed and highlighted. It was observed that the greatest interest in this field of research is 
concentrated in Italy, in which, six studies came from. The rest were from Brazil and France. About the type o study, six articles are experimental studies and four observational, one cohort and two casecontrols.

Regarding patients, the age ranged from 10 to 89 years old. Five clinical studies were performed with averaged 50 years old patients and only two articles were with patients in the elderly. In terms of gender, seven articles found a higher prevalence of psoriasis in men and the other three in women.

The theme psoriasis and food has been a target of interest, in order to outline nutritional strategies to improve the clinical status. Among the articles, five of them reported the relationship between psoriasis and food related to specific diets: three on a restricted energy diet; two on the Mediterranean diet and one on a gluten-free diet. The others related the disease to specific foods and/or nutrients, specially: coffee, two studies; pepper, one study; vitamin D, two studies and polyunsaturated fatty acids, three.

\section{Energy Restricted Diet}

The evidences indicate that obesity leads to development of psoriasis, and may also play a role in the worsening of existing psoriasis (JENSEN; SKOV, 2016), using pro inflammatory pathways that are present in white adipose tissue, which in people with obesity, favors an inflammatory low level condition, and this state is determining to the relation between obesity and autoimmune diseases. Obesity is a chronic disease in which excess energy deposits, causes the weight increase (KYLE et $a l ., 2016)$, and it is more prevalent in developed countries compared to developing ones (APOVIAN, 2016).

A randomized controlled trial study with 44 psoriatic patients and with a BMI > $30 \mathrm{~kg} / \mathrm{m}^{2}$, provided evidence that a diet with energy restriction has a positive impact on patients with obesity and psoriasis, in which along with the weight loss, there was a $50 \%$ reduction of PASI, and the significant improvement reported in the Quality of Life in Dermatology Index (GUIDA et al., 2014).

Also, a randomized controlled test with 303 patients with obesity and psoriasis, pointed that the intervention with the restricted diet combined with physical exercise led to reduced sensitivity of the disease (NALDI et al., 2014). Kong et al. (2019) demonstrated that it's important to considerate the patient's body weight, however, the focus on the loss of weight is because of the reducing of the adipokines secretion and inflammation induced by them in the obesity condition.

With respect to the secretion of adipokines, the highest level of factor tumor- $\alpha$ necrosis (TNF$\alpha$ ) is able to reduce adiponectin (SEREFLICAN et al., 2016), which plays regulatory role in skin inflammation, which contributes to the development of psoriasis in obesity (SHIBATA et al., 2015).

The

use of

TNF- $\alpha$

inhibitors in psoriatic patients has shown an increase in adiponectin, however, some studies indicate that the administration of anti-tumor alpha in the treatment of this disease may be correlated with weight gain (VOLOSHYNA et al., 2016).

A clinical non-randomized study with 45 patients, associated an energy restricted diet with the treatment with anti-TNF- $\alpha$ in patients with psoriasis, in order to avoid weight gain, and to get better response therapy with inhibitors of TNF$\alpha$ (CAMPANATI et al., 2017), since weight gain increases the secretion of adipokines and thus raises the level of necrosis factor $\alpha$ tumor, which in turn favors the development of psoriasis (SHIBATA et al., 2015).

Finally, the energy restricted diet prevents weight gain and consequently the increase of 
inflammation in obesity, playing an important role in clinical status of patients with obesity and psoriasis.

\section{Mediterranean Diet}

The Mediterranean diet, in addition to be a healthy dietary standard (SERRA-MAJEM; ORTIZANDRELLUCCHI, 2018), is considered a model of sustainable lifestyle (DERNINI et al., 2017) associated with reducing the risk of inflammation over a long period (AKBARALY et al., 2015). Thus, it reduces the risk of cardiovascular diseases (MARTÍNEZ-GONZÁLEZ et al., 2015), metabolic (DI DANIELE et al., 2017) and several chronic inflammatory diseases due to the large number of antioxidants and anti-inflammatories present in food (BILLINGSLEY; CARBONE, 2018). It is rich in fruits, vegetables, cereals, fish and extra virgin olive oil, with reduced consumption of dairy products, meat and eggs (VITIELLO et al., 2016).

A cross-sectional observational study with 62 individuals, found that the adherence to the Mediterranean diet and the higher consumption of extra virgin olive oil, that is, a source of monounsaturated fatty acid, is associated with a decrease in the severity of psoriasis (BARREA et al., 2015a). A similar type of study, conducted with 41 patients, based on the 7-day dietary records, found that the lower intake of monounsaturated fatty acid is linked to the progression of psoriasis (BARREA et $a l ., 2015 b)$ and higher PASI score (JAAKKOLA et al., 2018).

Another cohort study, carried out with 3557 psoriatic patients, found an association between adherence to the Mediterranean diet and the onset and/or severity of psoriasis (PHAN et al., 2018), in which they used MEDI-LITE, a score for scoring adherence to the Mediterranean diet (SOFI et al., 2017). The study found that patients with low levels of adherence to diet exhibited severe psoriasis (PHAN et al., 2018).

Therefore, in different studies and score types, PASI and MEDI-LITE, a positive relationship between an anti-inflammatory diet and the clinical status of psoriasis is perceived. In which, this evidence may support the hypothesis that the Mediterranean diet may delay the severity of psoriasis.

\section{Gluten-free Diet}

The celiac disease, an autoimmune disease that afflicts the small intestine primarily, improves when gluten is excluded from diet (CAIO et al., 2019), that is, a wheat-free diet (kamut, spelled and others), oats, barley and rye, ingredients that are found in bread, beer, pasta, cereals, wafer distributed in the Catholic Church, among other processed foods (MELINI; MELINI, 2019).

Some studies propose a link between psoriasis and sensitivity to gluten (NAGUI, et al., 2011; WU et al., 2012; AKBULUT, et al., 2013; KOLCHAK, et al., 2017). In a prospective multicenter study, in which 218 patients were evaluated, a significant improvement in PASI was found in patients who adhered to a gluten-free diet (BASTIANI et al., 2015).

However, a recent observational study found no association between gluten intake and psoriasis, but the type of study is limited, as it did not assess the impact of gluten intake on the severity of the disease (DRUCKER, et al., 2020). Given the above, for psoriatic patients with positive celiac antibodies, a diet excluding gluten may offer benefits in improving the clinical condition.

\section{Coffee}

Coffee is considered one of the most consumed beverages in the world (HIGASHI, 2019), 
it includes in its chemical composition, mainly, caffeine, caffeic acid, chlorogenic and diterpenes (cafestol and kahweol) (MOREIRA et al., 2017). It also includes other components that when biochemically active can have a huge impact on the etiology of diseases, such as cancer and inflammatory diseases (BULDAK et al., 2018).

The beneficial effects of caffeic acid (CA) have already been explored and found, for example, in cardiovascular conditions (VOSKOBOINIK et al., 2019), especially its performance as an antioxidant. However, it is important to note that this role occurs when it is used in a certain dose, up to $200 \mathrm{ml}$ per day (ZAMPELAS et al., 2004), if it exceeds this limit, it can act as a pro-oxidant (KHAN et al., 2016).

A Brazilian case-control study, carried out with 43 psoriatic patients, found that there was an improvement in the lesions when suspending the coffee from the diet, however the study did not use any score (FESTUGATO, 2011). There is still insufficient evidence to link coffee intake to the clinical status of psoriasis, so the relevance of the anti-inflammatory effect of this food on the disease is still unclear (SHARIF et al., 2017).

However, a cross-sectional observational case-control study with 221 psoriatic patients who drank 3 cups of coffee a day, demonstrated that they had low clinical severity with a lower PASI score (BARREA et al., 2018). Thus, it is possible to realize that coffee possibly does not act in the aggravation of the disease.

In addition, the routine intake of coffee can increase adiponectin, which is an adipokine with antiinflammatory effect. A recent in vitro study showed the ability of coffee to play an anti-inflammatory and immunosuppressive role (GOKCEN; ŞANLIER, 2019), this immunosuppressive activity is due to caffeine that acts by preventing the release of proinflammatory cytokines (FESTUGATO, 2011).

\section{Pepper}

Pepper is a capsaicinoid, that is, a set of several molecules with capsaicin, a substance that causes the aroma and spicy taste (SPILLER et al., 2008). Some studies report beneficial functions of capsaicin, such as anti-inflammatory, antioxidant and anti-itch (ANANDAKUMAR et al., 2008; BASITH et al., 2016,). It also works to improve cardiac, liver function and insulin sensitivity (PANCHAL et al., 2018).

However, capsaicin, can induce interleukin 8 (IL-8) in the intestinal epithelium, acting as a trigger for inflammation, as in psoriasis (FESTUGATO, 2011). In a study carried out with 43 psoriatic patients, it was found that $44.19 \%$ of them consumed pepper. After discontinuing consumption, $88.37 \%$ of the patients observed an improvement in the lesions (FESTUGATO, 2011). There are still few studies that relate pepper to the clinical condition of the disease, though.

\section{Vitamin D}

Vitamin D is an active mode of the steroid hormone originating from cholesterol, it can also be known as calcitrol or 1.25 - hydroxy vitamin D (FINAMOR et al., 2013). This vitamin is mainly synthesized in the skin by exposure to the sun and does not have much availability in food (BIZZARO et al., 2017). About $10 \%$ of the human genome has positions occupied by vitamin D receptors, even so the deficiency of this vitamin is very recurrent, and has been associated with several diseases, such as autoimmune ones (AZRIELANT; SHOENFELD, 2017).

A pilot clinical trial, carried out in Brazil, in which 9 patients with psoriasis participated, found a significant improvement in the disease, after six months of vitamin D3 supplementation (FINAMOR et al., 2013). Vitamin D plays an important role in 
immune homeostasis (ORGAZ-MOLINA et al., 2012) and is related to the significant decrease in the PASI score.

Even though it is available in foods such as salmon, sardines and egg yolks, in some cases supplementation is necessary (CHANG; LEE, 2019), with a daily recommendation of 200 to $600 \mathrm{IU}$ according to the RDA (BIZZARO et al., 2017).

\section{Polyunsaturated Fatty Acids (PUFAs)}

Fatty acids are considered fundamental substances for the structural design components of cells, organs and tissues, as well as for the formation of biologically active structures (SOKOLAWYSOCZANSKA et al., 2018). The definition of PUFAs is made by the position of the double or triple bond closest to the end of the fatty acid methyl group, the best known are PUFA Omega 3 and PUFA Omega 6 , both of which cannot be synthesized by mammals, so they must be consumed in the diet (MARION-LETELLIER et al., 2015).

PUFA $n-3$ is called linolenic acid (ALA), which through denaturation or elongation is converted into eicosapentaenoic acid (EPA) and docosahexaenoic acid (DHA), and PUFA n-6 is known as linoleic acid (LA) and gives rise to arachidonic acid (AA) and gamma-linolenic acid (GLA). AA is a precursor of prostaglandins, as which are an important element in inflammatory processes, in contrast, experimental evidence arising that the nutritional intervention with PUFA n-3, antagonize the metabolism of eicosanoids derived from $n-6$, generating anti-inflammatory prostaglandins (MARION-LETELLIER et al., 2015).

This anti-inflammatory effect of omega 3 is an essential component in wound recovery and tissue regeneration. Some enzymes involved in the synthesis of prostaglandins have demonstrated implications for psoriasis (GUIDA et al., 2014).
Dietary intervention, which alters the amount of omega 3 and 6 in the diet, has been shown to be effective in the clinical improvement of this disease (FESTUGATO, 2011, AFIFI et al. 2017).

The Western diet is low in PUFA n-3, which are found in foods such as fish, seafood, nuts, flaxseed and among other foods (GAMMONE et al., 2018). Afifi et al. (2017), when evaluating dietary interventions, reported that one of the most common and that generated improvement in skin lesions, was the consumption of fish oil, possibly omega 3 .

Research has increased and shown benefits of a diet rich in n-3 fatty acids for the skin (HUANG et al., 2018), a randomized clinical trial study conducted with 44 patients affected by plaque psoriasis, found improvement in disease severity, due to reduced PASI (GUIDA et al., 2014). Therefore, it is possible to verify a positive relationship between the clinical status of psoriasis and polyunsaturated fatty acids.

\section{CONCLUSION}

It is noticed that when it comes to discussing the issues related to psoriasis, many studies address nutrition trying to understand its impact on reducing or increasing the severity of the disease. It is already clear that some foods can have a negative influence, such as pepper and gluten, which are considered triggers. In the other hand, some can help controlling the disease, such as those that are part of the Mediterranean diet, which contains fish, olive oil, fruits, and vegetables. Another commonly explored factor is the positive impact of calorie-restricted diets in patients with obesity. There is a disease improvement as a result of an improved inflammatory profile due to weight reduction.

With regard to coffee, it possibly does not act in worsening the disease, but despite its known antioxidant effect, more research is needed to 
elucidate its influence on the clinical improvement of psoriasis.

Some nutrients do play a role in clinical improvement, such as vitamin $\mathrm{D}$, which is available in few foods, and the omega-3 fatty acid, which is highly available in fish. Although there are no dietary recommendations established by the psoriasis guidelines, the relationship between food, nutrients and psoriasis is clear. Therefore, individualized nutritional counseling for patients with psoriasis is of utmost importance, as appropriate nutritional guidance is able to promote improvement in clinical status.

Authors have declared that there is no potential conflict of interest regarding this article.

\section{REFERENCES}

AFIFI, L.; DANESH, M.J.; LEE, K.M.; BEROUKHIM, K.; FARAHNIK, B.; et al. Dietary Behaviors in Psoriasis: Patient-Reported Outcomes from a U.S. National Survey. Dermatology and therapy, 2017, v.7, n.2, p. 227-242. Doi:10.1007/s13555-017-0183-4

AKBARALY, T.N.; SHIPLEY, M.J.; FERRIE, J.E.; VIRTANEN, M.; LOWE, G.; et al. Long-term adherence to healthy dietary guidelines and chronic inflammation in the prospective Whitehall II study. The American Jounal of Medicine. 2015, v.128, n.2, p.152-160.e4. Doi:10.1016/j.amjmed.2014.10.002.

AKBULUT, S.; GUR, G.; TOPAL, F.; SENEL, E.; TOPAL, F.; et al. Saritas Ü. Celiac DiseaseAssociated Antibodies in Psoriasis. Annals of Dermatology, 2013，v.25, p.298. Doi: 10.5021 / ad.2013.25.3.298.

ANANDAKUMAR, P.; KAMARAJ, S.; JAGAN, S.; RAMAKRISHNAN， G.; VINODJKUMAR， R.; DEVAKI, T. Capsaicin modulates pulmonary antioxidant defense system during benzo(a)pyreneinduced lung cancer in swiss albino mice. Phytotherapy Research, 2008 v.22, p.529-533. Doi: $10.1002 /$ ptr.2393
AZRIELANT, S.; SHOENFELD, Y. Vitamin D and the Immune System. The Israel Medical Associations Journal, 2017, v.19, n.8, p.510-511. Disponível em: https://pubmed.ncbi.nlm.nih.gov/28825771/?from ter $\underline{m}=$ vitamin+D\&from_filter=simsearch2.ffrft\&from_fi lter=ds1.y_5\&from_page $=4 \&$ from_pos $=9$

BARREA, L.; BALATO, N.; DI SOMMA, C.; MACCHIA, P.E.; NAPOLITANO, M.; et al. Nutrition and psoriasis: is there any association between the severity of the disease and adherence to the Mediterranean diet?. Journal of translational medicine, 2015a, v.13, n.18. Doi:10.1186/s12967$\underline{014-0372-1}$

BARREA, L.; MACCHIA, P.E.; TARANTINO, G.; DI SOMMA, C.; PANE, E.; et al. Nutrition: a key environmental dietary factor in clinical severity and cardio-metabolic risk in psoriatic male patients evaluated by 7-day food-frequency questionnaire. Journal of Translational Medicine. 2015b, v.13, p.303. Doi:10.1186/s12967-015-0658-y

BARREA, L.; MUSCOGIURI, G.; DI SOMMA, C.; ANNUZIATA, G.; MEGNA, M.; et al. Coffee consumption, metabolic syndrome and clinical severity of psoriasis: good or bad stuff?. Archives Toxicology. 2018, v.92, n.5. p.1831-1845. Doi:10.1007/s00204-018-2193-0

BARREA, L.; NAPPI, F.; DI SOMMA, C.; SAVANELLI, M.M.; FALCO, A.; et al. Environmental Risk Factors in Psoriasis: The Point of View of the Nutritionist. International Journal of Environmental Research and Public Health, 2016, v.13, n.5, p.743. Doi:10.3390/ijerph13070743

BASITH, S.; CUI, M.; HONG, S.; CHOI, S. Harnessing the Therapeutic Potential of Capsaicin and Its Analogues in Pain and Other Diseases. Molecules. 2016, v.21, n.8, p.966. Doi:10.3390/molecules21080966

BASTIANI, R.; GABRIELLI, M.; LORA, L.; NAPOLI, L.; TOSETTI, C.; et al. Association between coeliac disease and psoriasis: Italian primary care multicentre study. Dermatology. 2015, v.230, n.2, p.156-160. Doi:10.1159/000369615 
BILLINGSLEY, H.E.; CARBONE, S. The antioxidant potential of the Mediterranean diet in patients at high cardiovascular risk: an in-depth review of the PREDIMED. Nutrition \& Diabetes. 2018, v.8, n.1, p.13. Doi:10.1038/s41387-018-0025-1

BIZZARO, G.; ANTICO, A.; FORTUNATO, A.; BIZZARO, N. Vitamin D and Autoimmune Diseases: Is Vitamin D Receptor (VDR) Polymorphism the Culprit?. The Israel Medical Association Journal. 2017, v.19, n.7, p.438-443. Disponível em: https://pubmed.ncbi.nlm.nih.gov/28786260/

BOEHNCKE，W.H.; SCHON， M.P. Psoríase. The Lancet, 2015, v.386, p.983-994. Doi: 10.1016 / s0140-6736 (14) 61909-7

BRAATHEN, L.R.; BOTTEN, G.; BJERKEDAL, T. Prevalence of psoriasis in Norway. Acta DermatoVenereologica Supplementum, 1989, v.142, n.5-8. Disponível em: https://pubmed.ncbi.nlm.nih.gov/2763787/.

BULDAK, R.J.; HEJMO, T.; OSOWSKI, M.; BULDAK, L.; KUKLA, M.; et al. The Impact of Coffee and Its Selected Bioactive Compounds on the Development and Progression of Colorectal Cancer In Vivo and In Vitro. Molecules, 2018, v.23, n.12, p.3309. Doi:10.3390/molecules23123309.

CAIO, G.; VOLTA, U.; SAPONE, A.; LEFFLER, D.A.; GIORGIO, R.D.; et al. Celiac disease: a comprehensive current review. BMC Medicine, 2019, v.17, n.1, p.142. Doi:10.1186/s12916-0191380-z.

CAMPANATI, A.; MOLINELLI, E.; GANZETTI, G.; GIULIODORI, I.; MINETTI, M.; et al. The effect of low-carbohydrates calorie-restricted diet on visceral adipose tissue and metabolic status in psoriasis patients receiving TNF-alpha inhibitors: results of an open label controlled, prospective, clinical study. Journal of Dermatological Treatment. 2017, v.28, n.3, p.206-212. Doi:10.1080/09546634.2016.1214666.

CHANG, S.W.; LEE, H.C. Vitamin D and health The missing vitamin in humans. Pediatrics and Neonatology. 2019, v.60, n.3, p.237-244. Doi:10.1016/j.pedneo.2019.04.007
CHANG, Y.T.; CHEN, T.J.; LIU, P.C.; CHEN, Y.C.; CHEN, Y.J.; et al. Epidemiological study of psoriasis in the national health insurance database in Taiwan. Acta Dermato- Venereologica, 2009, v.89, p.262-6. Doi: 10.2340 / 00015555-0642.

DERNINI, S.; BERRY, E.M.; SERRA-MAJEM, L.; LA VECHIA, C.; CAPONE, C.; et al. Med Diet 4.0: the Mediterranean diet with four sustainable benefits. Public Health Nutrition. 2017, v.20, n.7, p.1322-1330. Doi:10.1017/S1368980016003177

DI DANIELE, N.; NOE, A.; VIDIRI, M.F.; MORICONI, E.; MARRONE, G.; et al. Impact of Mediterranean diet on metabolic syndrome, cancer and longevity. Oncotarget, 2017, v.8, n.5, p.89478979. Doi:10.18632/oncotarget.13553

DING, X.; WANG, T.; SHEN, Y.; WANG, X.; ZHOU, C.; et al. Prevalence of psoriasis in China: a population-based study in six cities. European Journal of Dermatology, 2012, v.22, p.663-7. Doi: 10.1684 / ejd.2012.1802

DRUCKER, A.M.; QURESHI, A.A.; THOMPSON, J.M.; LI, T.; CHO, E. Gluten intake and risk of psoriasis, psoriatic arthritis, and atopic dermatitis among United States women. Journal of the American Academy Dermatology, 2020, v.82, n.3, p.661-665. Doi: 10.1016/j.jaad.2019.08.007.

FESTUGATO, M. Estudo piloto sobre alimentos que devem ser evitados nos portadores de psoríase. Anais Brasileiros de Dermatologia. Rio de Janeiro, v.86, n.6, p.1103-1108, 2011. Doi:10.1590/S0365-05962011000600006 .

FINAMOR, D.C.; SINIGAGLIA-COIMBRA, R.; NEVES, L.C.; GUTIERREZ, M.; SILVA, J.J.; et al. A pilot study assessing the effect of prolonged administration of high daily doses of vitamin $D$ on the clinical course of vitiligo and psoriasis. Dermatoendocrinology, 2013, v.5, n.1, p.222-234. Doi.org/104161/derm.24808

FOX, H. DERMATOLOGY OF THE ANCIENTS. Journal of the American Medical Association, 1915 , p.469. Doi:10.1001/jama.1915.02580060001001. 
GAMMONE, M.A.; RICCIONI, G.; PARRINELLO, G.; D'ORAZIO, N. Omega-3 Polyunsaturated Fatty Acids: Benefits and Endpoints in Sport. Nutrients. 2018, v.11, n.1, p.46. Doi:10.3390/nu11010046

GELFAND, J.M.; FELDMAN, S.R.; STERN, R.S.; THOMAS, J.; ROLSTAD, T.; MARGOLIS, D.J. Determinants of quality of life in patients with psoriasis: a study of the United States population. Journal of the American Academy of Dermatology, 2004, v.51, n.5, p.704-708. Doi: 10.1016 / j.jaad.2004.04.014

GELFAND, J.M.; WEINSTEIN, R.; PORTER, S.B.; NEIMANN, A.L.; BERLIN, J. A.; MARGOLIS, D.J. Prevalence and Treatment of Psoriasis in the United Kingdom. Archives of Dermatology, 2005, v.141, n.12. Doi:10.1001/archderm.141.12.1537

GOKCEN, B.B.; ŞANLIER, N. Coffee consumption and disease correlations. Critical Reviews in Food Science and Nutricion. 2019, v.59, n.2, p.336-348. Doi:10.1080/10408398.2017.1369391

GUIDA, B.; NAPOLEONE, A.; TRIO, R.; NASTASI, A.; BALATO, N.; et al. Energyrestricted, n-3 polyunsaturated fatty acids-rich diet improves the clinical response to immuno-modulating drugs in obese patients with plaque-type psoriasis: a randomized control clinical trial. Clinical Nutrition. 2014, v.33, n.3, p.399-405. Doi: 10.1016/j.clnu.2013.09.010

HIGASHI, Y. Coffee and Endothelial Function: A Coffee Paradox?. Nutrients, 2019, v.11, n.9, p.2104. Doi:10.3390/nu11092104

HUANG, T.H.; WANG, P.W.; YANG, S.C.; CHOU, W.L.; FANG, J.Y. Cosmetic and Therapeutic Applications of Fish Oil's Fatty Acids on the Skin. Marine Drugs. 2018, v.16, n.8, p.256. Doi:10.3390/md16080256

HULSE, EV. The nature of biblical "leprosy" and the use of alternative medical terms in modern translations of the Bible. Palestine Exploration Quartely, 1975, v.107, p.87-105. Doi: 10.1017 / s0025727300022250.
IFPA. INTERNATIONAL FEDERATION OF PSORIASIS ASSOCIATIONS. Acesso em 28 de Outubro, 2020. https://ifpa-pso.com/

JAAKKOLA, M.K.; MCGLINCHEY, A.J.; KLÉN, R.; ELO, L.L. PASI: A novel pathway method to identify delicate group effects. PLoS One. 2018, v.13, n.7, p.e0199991.

Doi:10.1371/journal.pone.0199991

JENSEN, P.; SKOV, L. Psoriasis and Obesity. Dermatology. 2016, v.232, n.6, p.633-639. Doi: $10.1159 / 000455840$

KHAN, F.A.; MAALIK, A.; MURTAZA, G. Inhibitory mechanism against oxidative stress of caffeic acid. Journal of Food Drug Analysis. 2016, v.24, n.4, p.695-702. Doi:10.1016/j.jfda.2016.05.003

KIM, W.B.; JEROME, D.; YEUNG, J. Diagnosis and management of psoriasis. Canadian Family Physician Medecin, 2017, v.63, n.4, p.278-285.

KOLCHAK, N.A.; TETARNIKOVA, M.K.; THEODOROPOULOU, M.S.; MICHALOPOULOU, A.P.; THEODOROPOULOS, D.S. Prevalence of antigliadin IgA antibodies in psoriasis vulgaris and response of seropositive patients to a gluten-free diet. Journal of Multidisciplinary Healthcare, 2017, v.11, p.13-19. Doi: 10.2147/JMDH.S122256.

KONG, Y.; ZHANG, S.; WU, R.; SU, X.; PENG, D.; et al. New insights into different adipokines in linking the pathophysiology of obesity and psoriasis. Lipids in Health and Disease. 2019, v.18, n.1, p.171. Doi:10.1186/s12944-019-1115-3

KORMAN, N.J.; ZHAO, Y.; PIKE, J.; ROBERTS, J. Relationship between psoriasis severity, clinical symptoms, quality of life and work productivity among patients in the USA. Clinical and Experimental Dermatology, 2016, v.41, n.5, p.514521. Doi:10.1111/ced.12841

KURD, S.K.; GELFAND, J.M. The prevalence of previously diagnosed and undiagnosed psoriasis in adults in the USA: Results of the NHANES 20032004. Journal of the American Academy of Dermatology, 2009, v.60, n.2, p.218-224. Doi: 10.1016 / j.jaad.2008.09.022 
KYLE，T.K.; DHURANDHAR, E.J.; ALLISON, D.B. Regarding Obesity as a Disease: Evolving Policies and Their Implications. Endocrinology and Metabolism Clinics of North America. 2016, v.45, n.3, p.511-520. Doi:10.1016/j.ecl.2016.04.004

MARION-LETELLIER, R.; SAVOYE, G.; GHOSH, S. Polyunsaturated fatty acids and inflammation. International Union of Biochemistry and Molecular Biology Life. 2015, v.67, n.9, p.659667. Doi:10.1002/iub.1428

\section{MARTÍNEZ-GONZÁLEZ, M.A.; SALAS-} SALVADÓ, J.; ESTRUCH, R.; CORELLA, D.; FITÓ, M.; et al. Benefits of the Mediterranean Diet: Insights From the PREDIMED Study. Progress in Cardiovascular Diseases. 2015, v.58, n.1, p.50-60. Doi:10.1016/j.pcad.2015.04.003

MELINI, V.; MELINI, F. Gluten-Free Diet: Gaps and Needs for a Healthier Diet. Nutrients, 2019, v.11, n.1, p.170. Doi:10.3390/nu11010170

MOREIRA, A.S.P.; NUNES, F.M.; SIMÕES, C.; MACIEL, E.; COIMBRA, A.M.; et al. Data on coffee composition and mass spectrometry analysis of mixtures of coffee related carbohydrates, phenolic compounds and peptides. Data in Brief. 2017, v.13, p.145-161. Doi:10.1016/j.dib.2017.05.027

NAGUI, N.; EL NABARAWY, E.; MAHGOUB, D.; MASHALY, H.; SAAD, N.; et al. Estimation of (IgA) anti-gliadina, anti-endomísio e transglutaminase de tecido no soro de pacientes com psoríase . Clinical and Experimental Dermatology, 2011, v.36, p.302-304. Doi: 10.1111 / j.13652230.2010.03980.x.

NALDI, L.; CONTI, A.; CAZZANIGA, S.; PATRIZI, A.; PAZZAGLIA, M.; et al. Diet and physical exercise in psoriasis: a randomized controlled trial. British Journal of Dermatology. 2014, v.170, n.3, p.634-642. Doi:10.1111/bjd.12735

ORGAZ-MOLINA，J.; BUENDÍA-EISMAN， A.; ARRABAL-POLO, M.A.; RUIZ, J.C.; ARIASSANTIAGO, S. Deficiency of serum concentration of 25-hydroxyvitamin D in psoriatic patients: a casecontrol study. Journal of the American Academy
Dermatology, 2012, v.67, n.5, p.931-8. Doi: 10.1016/j.jaad.2012.01.040.

PANCHAL, S.K.; BLISS, E.; BRONW, L. Capsaicin in Metabolic Syndrome. Nutrients. 2018, v.10, n.5, p.630. Doi:10.3390/nu10050630

PATALAY, R.; LESLIE, K.S.; LEVELL, N.J. Robert Willan and the age of enlightenment. International Journal of Dermatology, 2008, v.47, p.297-300. Doi: 10.1111 / j.1365-4632.2008.03355.x

PHAN, C.; TOUVIER, M.; KESSE-GUYOT, E.; ADJIBADE, M.; HERCBERG, S.; et al. Association Between Mediterranean Anti-inflammatory Dietary Profile and Severity of Psoriasis: Results From the NutriNet-Santé Cohort. JAMA dermatology. 2018, v.154, n.9, p.1017-1024. Doi:10.1001/jamadermatol.2018.2127.

PSORIASE BRASIL. Associação Brasileira de Psoríase, Artrite Psoriásica e de Outras Doenças Crônicas de Pele. Acesso em Fevereiro, 2021. https://psoriasebrasil.org.br/

RENDON, A.; SCHAKEL, K. Psoriasis Pathogenesis and Treatment. International Journal of Molecular Sciences, v.20, n.6, p.1475, 2019. Doi:10.3390/ijms20061475

SEREFLICAN, B.; GOKSUGUR, N.; BUGDAYCI, G.; POLAT, M.; HAYDAR, P.A. Serum Visfatin, Adiponectin, and Tumor Necrosis Factor Alpha (TNF- $\alpha$ ) Levels in Patients with Psoriasis and their Correlation with Disease Severity. Acta Dermatovenerol Croat. 2016, v.24, n.1, p.13-19. Disponível em: https://pubmed.ncbi.nlm.nih.gov/27149125/

SERRA-MAJEM, L.; ORTIZ-ANDRELLUCCHI, A. The Mediterranean diet as an example of food and nutrition sustainability: a multidisciplinary approach. Nutricion Hospitalaria, 2018, v.35, p.96101. Doi:10.20960/nh.2133.

SHARIF, K.; WATAD, A.; BRAGAZZI, N.L.; ADAWI, M.; AMITAL, H.; et al. Coffee and autoimmunity: More than a mere hot beverage!. Autoimmunity Reviews. 2017, v.16, n.7, p.712-721. Doi:10.1016/j.autrev.2017.05.007 
SHIBATA, S.; TADA, Y.; HAU, C.S.; MITSUI, A.; KAMATA, M.; et al. Adiponectin regulates psoriasiform skin inflammation by suppressing IL-17 production from $\gamma \delta$-T cells. Nature Communications. 2015, v.6, p.7687. Doi: $10.1038 /$ ncomms 8687

SOFI, F.; DINU, M.; PAGLIAI, G.; MARCUCCI, R.; CASINI, A. Validation of a literature-based adherence score to Mediterranean diet: the MEDILITE score. International Journal of Food Sciences and Nutricion. 2017, v. 68, n. 6, p. 757-762. Doi: $10.1080 / 09637486.2017 .1287884$

SOKOLA-WYSOCZANSKA, E.; WYSOCZANSKI, T.; WAGNER, J.; CZYZ, K.; BODKOWSKI, R.; et al. Polyunsaturated Fatty Acids and Their Potential Therapeutic Role in Cardiovascular System Disorders-A Review. Nutrients. 2018, v.10, n.10, p.1561. Doi:10.3390/nu10101561

SPILLER, F.; ALVES, M.K.; VIEIRA, S.M.; CARVALHO, T.A.; LEITE, C.E.; et al. Antiinflammatory effects of red pepper (Capsicum baccatum) on carrageenan- and antigen-induced inflammation. Journal of Pharmacy and Pharmacology, 2008, v.60, p.473-478. Doi:10.1211/jpp.60.4.0010

STERN, R.S.; NIJSTEN, T.; FELDMAN， S.R.; MARGOLIS, D.J.; ROLSTAD, T. Psoriasis Is Common, Carries a Substantial Burden Even When Not Extensive, and Is Associated with Widespread Treatment Dissatisfaction. Journal of Investigative Dermatology Symposium Proceedings, 2004, v.9, n. 2 , p.136-139. Doi:10.1046/j.1087-
TAKESHITA, J.; GREWAL, S.; LANGAN, S.M.; MEHTA, N.N.; OGDIE, A.; et al. Psoriasis and comorbid diseases: Epidemiology. Journal of the American Academy of Dermatology. 2017, v.76, n.3, p.377-390. Doi: 10.1016/j.jaad.2016.07.064.

VITIELLO, V.; GERMANI, A.; CAPUZZO, D.E.; DONINI, L.M.; DEL BALZO, V. The New Modern Mediterranean Diet Italian Pyramid. Annali di Igiene: medicina preventiva e di comunita. 2016, v.28, n.3, p.179-186. Doi:10.7416/ai.2016.2096

VOLOSHYNA, I.; MOUNESSA, J.; CARSONS, S.E.; \& REISS, A.B. Effect of inhibition of interleukin-12/23 by ustekinumab on the expression of leptin and leptin receptor in human THP-1 macrophages. Clinical and experimental dermatology, 2016, v.41, n.3, p.308-311. Doi.org/10.1111/ced.12699

VOSKOBOINIK, A.; KOH, Y.; KISTLER, P.M. Cardiovascular effects of caffeinated beverages. Trends in Cardiovascular Medicine. 2019, v.29, n.6, p.345-350. Doi: 10.1016/j.tcm.2018.09.019.

ZAMPELAS, A.; PANAGIOTAKOS, D. B.; 55 PITSAVOS, C.; CHRYSOHOOU, C.; STEFANADIS, C. Associações entre o consumo de café e marcadores inflamatórios em pessoas saudáveis: o estudo ATTICA. The American Journal of Clinical Nutrition, 2004, v. 80, n. 4, p. 862-867. Doi: 10.1093 / ajen / 80.4.862.

WU, J.J.; NGUYEN, T.U.; POON, K.Y.T.; HERRINTON, L.J.; LISA, J. The association of psoriasis with autoimmune diseases. Journal of the American Academy of Dermatology, 2012, v.67, n.5, p.924-930. Doi:10.1016/j.jaad.2012.04.039 